\title{
Three-dimensional modeling of pseudoelastic effect of the shape memory alloys
}

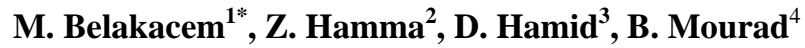 \\ ${ }^{1}$ Department of Mechanical Engineering, University of Batna, Algeria \\ samsum66@gmail.com \\ ${ }^{2}$ Department of Mechanical Engineering, University of Khenchela, Algeria \\ zedirahamma2003@yahoo.fr \\ ${ }^{3}$ Department of mechanical Engineering, University of Khenchela, Algeria \\ h_djebaili@yahoo.fr \\ ${ }^{4}$ Department of Mechanical Engineering, University of Batna, Algeria \\ brio_ray@hotmail.com \\ *Corresponding author
}

\begin{abstract}
The present work aims to develop a 3D constitutive model to describe pseudoelastic effect on the behavior of memory shape alloys. This phenomenological constitutive model is based on a set of variables: temperature and stress as control variables, and the fraction of the martensite as an internal variable. By using the first and the second principle of thermodynamics and with a simple formalism, we have developed constitutive equations followed by criteria of transformations. This developed model has parameters intended to be determined by a tensile pseudoelastic test. We have introduced an algorithm to simulate the response of the model with respect to experimental data. Three cases were considered: one dimensional, biaxial and triaxial loading.
\end{abstract}

Keywords: constitutive relations, martensite fraction, shape memory alloys, pseudoelastic effect.

\section{Introduction}

In the last decades, the materials field development has seen an extraordinary progress because of new applications of materials. The shape memory alloys, which belong to a particular group of materials called smart materials, form an interesting part of the entirely new used materials. These materials exhibit a unique behavior in comparison with conventional materials. Researchers, scientists and engineers were attracted by this behavior, so several studies were pursued to understand this behavior and find behavior laws. Consequently, a large number of models have been developed. Because of their properties, these materials are introduced into numerous areas such as biomedical field, car industry, aerospatial applications, aviation field and others (Lagoudas et al. 2004). By using these materials, many alternatives which appear economical and practical were adopted. The use of such materials requires a good description of the constitutive law. 
Due to their diversity, these models can be classified into three categories:

- Micromechanical models: These models describe material behavior rigorously, but their implementation in the finite continuum numerical computer codes remains difficult. The pioneers of these types of models were Wechsler (Wechsler et al. 1953) and Falk (Falk et al. 1980), with many improvements in (Ball et al. 1992, Battacharya et al. 1999).

- $\quad$ Phenomenological models: These types of models are used in engineering because of their simple formulations but with a low accuracy (Tanaka et al. 1986, Brinson et al. 1993, Lexcellent et al. 2000, Lagoudas et al. 2004).

- Micro-macroscopic models: These models are developed by combination of the two above approaches (Patoor et al. 1993, Chu et al. 1995, Lexcellent et al. 1996, Huang et al. 1998)

Our developed constitutive model belongs to the second category, where we have considered three dimensional pseudoelastic effect on the material behavior. This model is intended to be used in engineering field. The presentation is divided into the following sections: the first section is devoted to building of the model by writing constitutive equation, the second section is dedicated to simulation of the response of the model in three cases: one dimensional, two dimensional and three dimensional loading conditions. Finally, the last section presents the discussion of the obtained results.

\section{Methods and materials}

\subsection{Presentation of the pseudoelastic effect}

The pseudoelasticity effect is obtained when the alloy is submitted to a thermomechanical loading composed of a heating cycle above a temperature $T^{1}>A_{f}^{0}$ (temperature of the end of austenite transformation), followed by a mechanical loading when the material undergoes a large deformation. When the applied mechanical loading is removed, the alloy recovers its initial shape. (Fig. 1)

\subsection{Constitutive equations:}

We choose the following expression of the density of Gibbs free energy:

$G(\sigma, T, f)=-Q \cdot \sigma: S_{A}: \sigma-(1-Q) \cdot \sigma: S_{M}: \sigma-f . \varepsilon_{0} \cdot \sigma: R+f . B .\left(T-M_{s}^{0}\right)+C . f .(1-f)$

where:

$\sigma:$ Stress tensor of Cauchy

$Q$ : Controller coefficient of elastic energy of martensite or austenite

$Q=\left\{\begin{array}{l}1 \text { If there is elastic deformation of austenite } \\ 0 \text { If there is elastic deformation of martensite }\end{array} \Rightarrow Q=\left\{\begin{array}{l}1 \text { if } \dot{f} \neq 0 \text { et } f=0 \\ 0 \text { if } \dot{f} \neq 0 \text { et } f=1\end{array}\right.\right.$

$S_{A}$ and $S_{M}: 4^{\text {th }}$ order tensor of compliance of austenite and martensite, respectively

Q. $\sigma: S_{A}: \sigma:$ Elastic energy of deformation of austenite

$(1-Q) . \sigma: S_{M}: \sigma$ : Elastic energy of deformation of martensite

$R: 2^{\text {nd }}$ order tensor of transformation: 


$$
R_{i j}=\frac{\sigma_{i j}}{\sqrt{\sigma: \sigma}}
$$

f. $\varepsilon_{0} . \sigma: R$ : Mechanical work associated with the transformation of martensite

f.B. $\left(T-M_{S}^{0}\right)$ : Free energy of phase change

C. $f .(1-f)$ : Energy of interaction between martensite and austenite

$\varepsilon_{0}$ : Maximum deformation along an axis

$f$ : Fraction of martensite $(f \geq 0$ et $f \leq 1)$

$B$ : Coefficient related to energy of phase change, to be determined by a tensile test of pseudoelasticity

C: Coefficient related to interaction energy, to be determined by a tensile test of pseudoelasticity

$M_{S}^{0}$ : Temperature of start of martensite transformation

Assuming that the dissipation is associated only with the transformation of martensite, the second law of thermodynamics can be written as (Patoor et al. 1993, Lagoudas et al. 2004):

$$
\frac{\partial G}{\partial f} \geq 0
$$

Let us write (3) as follows:

$$
-\frac{\partial G}{\partial f}=F^{t h}
$$

where $F^{\text {th }}$ is the driving force.

Criteria of transformation. The driving force can be written as follows:

$$
F^{t h}=-\frac{\partial G}{\partial f}=\varepsilon_{0} \cdot \sigma: R-B .\left(T-M_{s}^{0}\right)+C \cdot(2 f-1)
$$

The dissipative force (Patoor et al. 1993) can be expressed by:

$$
F^{d i}=K f+H
$$

where $K$ and $H$ are coefficients related to dissipativity, and they are to be determined by a tensile test of pseudoelasticity.

The forward and reverse transformations occur when the following conditions are satisfied:

$$
\left\{\begin{array}{cl}
F^{t h}=F^{d i} ; \dot{f}>0 & \text { forward transformation } \\
F^{t h}=-F^{d i} ; \dot{f}<0 & \text { reverse transformation }
\end{array}\right.
$$

Let us introduce the criterion function $\varphi(\sigma, T, f)$ as:

$$
\varphi(\sigma, T, f)=\left\{\begin{array}{l}
\varepsilon_{0} . \sigma: R-B .\left(T-M_{s}^{0}\right)+C .(2 f-1)+K f+H ; \dot{f}>0 \\
\varepsilon_{0} . \sigma: R-B .\left(T-M_{s}^{0}\right)+C .(2 f-1)-K f-H ; \dot{f}<0
\end{array}\right.
$$

When the forward transformation occurs we have:

$$
\varphi^{d i}(\sigma, T, f)=0
$$

The consistence conditions are:

$$
d \varphi^{d i}(\sigma, T, f)=0
$$




$$
\begin{gathered}
\frac{\partial \varphi^{d i}}{\partial \sigma} d \sigma+\frac{\partial \varphi^{d i}}{\partial T} d T+\frac{\partial \varphi^{d i}}{\partial f} d f=0 \\
\varepsilon_{0} \cdot R: d \sigma-B d T+(2 C-K) d f=0
\end{gathered}
$$

From equation (12) we can obtain the evolution of the martensite fraction:

$$
d f=\frac{\varepsilon_{0} \cdot R: d \sigma-B d T}{(K-2 C)}
$$

while for the reverse transformation we have:

$$
d f=-\frac{\varepsilon_{0} \cdot R: d \sigma-B d T}{(K+2 C)}
$$

The expression of the total strain can be written as:

$$
\begin{gathered}
\varepsilon=-\frac{\partial G}{\partial \sigma} \\
\varepsilon=Q . S_{A}: \sigma+(1-Q) . S_{M}: \sigma+f . \varepsilon_{0} \cdot R
\end{gathered}
$$

Total strain can be divided into elastic and nonlinear terms:

$$
\varepsilon=\varepsilon^{e}+\varepsilon^{t}
$$

where we have

$\varepsilon^{e}$ - elastic strain, and $\varepsilon^{t}$ - nonlinear strain due to transformation, which are

$$
\begin{gathered}
\varepsilon^{e}=Q \cdot S_{A}: \sigma+(1-Q) \cdot S_{M}: \sigma \\
\varepsilon^{t}=f \cdot \varepsilon_{0} \cdot R
\end{gathered}
$$

and

$$
d \varepsilon=d \varepsilon^{e}+d \varepsilon^{t}
$$

Equation (19) can be written in the form:

$$
d \varepsilon^{t}=d f \cdot \varepsilon_{0} \cdot R
$$

and using (13) and (21), it follows:

$$
\begin{gathered}
d \varepsilon^{t}=\left(\frac{\varepsilon_{0} \cdot R: d \sigma-B d T}{(K-2 C)}\right) \cdot \varepsilon_{0} \cdot R \\
d \varepsilon^{t}=\frac{\varepsilon_{0}{ }^{2}}{(K-2 C)} R \times R: d \sigma-\frac{\varepsilon_{0} B R}{(K-2 C)} d T
\end{gathered}
$$

In case of reverse transformation we have:

$$
d \varepsilon^{t}=-\frac{\varepsilon_{0}^{2}}{(K+2 C)} R \times R: d \sigma+\frac{\varepsilon_{0} B R}{(K+2 C)} d T
$$

where $\times$ denotes the tensor product.

Equation (24) shows the control of the transformation by stress and temperature.

Let us write the term related to the stress:

$$
E C S= \begin{cases}\frac{\varepsilon_{0}{ }^{2}}{(K-2 C)} R \times R ; & \text { for } \quad \dot{f}>0 \\ -\frac{\varepsilon_{0}{ }^{2}}{(K+2 C)} R \times R ; & \text { for } \dot{f}<0\end{cases}
$$

The analogous relations follow for the term related to the temperature: 


$$
E C T= \begin{cases}-\frac{\varepsilon_{0} B R}{(K-2 C)} ; & \text { for } \dot{f}>0 \\ \frac{\varepsilon_{0} B R}{(K+2 C)} ; & \text { for } \dot{f}<0\end{cases}
$$

Equation (23) can then be written as:

$$
d \varepsilon^{t}=E C S: d \sigma+E C T . d T
$$

where:

ECS: $4^{\text {th }}$ order tensor of complaisance associated with transformation controlled by stress

ECT: $4^{\text {th }}$ order tensor of complaisance associated with transformation controlled by temperature

In case the condition is isothermal $d T=0$ (pseudoelastic effect behavior), then equations (13) and (14) become:

$$
\begin{gathered}
d f=\frac{\varepsilon_{0} \cdot R: d \sigma}{(K-2 C)} \\
d f=-\frac{\varepsilon_{0} \cdot R: d \sigma}{(K+2 C)}
\end{gathered}
$$

Under these conditions, equation (27) takes the following form:

$$
d \varepsilon^{t}=\frac{\varepsilon_{0}^{2}}{(K-2 C)} R \times R: d \sigma
$$

and for reverse transformation:

$$
d \varepsilon^{t}=-\frac{\varepsilon_{0}^{2}}{(K+2 C)} R \times R: d \sigma
$$

\subsection{Determination of constants $B, C, K$ and $H$}

To determine these constants we use one dimensional tensile test of pseudoelasticity at $T=T_{1}$.

At the start of the forward transformation we have:

$$
f=0 ; T=T 1 ; \sigma=\left(\begin{array}{ccc}
\sigma_{M S} & 0 & 0 \\
0 & 0 & 0 \\
0 & 0 & 0
\end{array}\right) ; \quad R=\left(\begin{array}{ccc}
1 & 0 & 0 \\
0 & 0 & 0 \\
0 & 0 & 0
\end{array}\right)
$$

At the end of the forward transformation:

$$
\mathrm{f}=1 ; \mathrm{T}=\mathrm{T} 1 ;=\left(\begin{array}{ccc}
\sigma_{M f} & 0 & 0 \\
0 & 0 & 0 \\
0 & 0 & 0
\end{array}\right) ; \quad R=\left(\begin{array}{ccc}
1 & 0 & 0 \\
0 & 0 & 0 \\
0 & 0 & 0
\end{array}\right)
$$

At the start of the reverse transformation:

$$
\mathrm{f}=1 ; \mathrm{T}=\mathrm{T} 1 ; \sigma=\left(\begin{array}{ccc}
\sigma_{A s} & 0 & 0 \\
0 & 0 & 0 \\
0 & 0 & 0
\end{array}\right) ; \quad R=\left(\begin{array}{ccc}
1 & 0 & 0 \\
0 & 0 & 0 \\
0 & 0 & 0
\end{array}\right)
$$

At the end of the reverse transformation:

$$
\mathrm{f}=0 ; \mathrm{T}=\mathrm{T} 1 ;=\left(\begin{array}{ccc}
\sigma_{A f} & 0 & 0 \\
0 & 0 & 0 \\
0 & 0 & 0
\end{array}\right) ; \quad R=\left(\begin{array}{ccc}
1 & 0 & 0 \\
0 & 0 & 0 \\
0 & 0 & 0
\end{array}\right)
$$

With conditions (32) corresponding to $\varphi^{d i}\left(\sigma=\sigma_{M S}, T=T 1, f=0\right)=0$, we have 


$$
\varepsilon_{0} \cdot \sigma_{M S}-B \cdot\left(T 1-M_{S}^{0}\right)-C-H=0
$$

With conditions (33) corresponding to $\varphi^{d i}\left(\sigma=\sigma_{M f}, T=T 1, f=1\right)=0$, we have

$$
\varepsilon_{0} . \sigma_{M f}-B .\left(T 1-M_{S}^{0}\right)+C-K-H=0
$$

With conditions (34) corresponding $\varphi^{r e}\left(\sigma=\sigma_{A s}, T=T 1, f=1\right)=0$, we have

$$
\varepsilon_{0} \cdot \sigma_{A s}-B .\left(T 1-M_{s}^{0}\right)+C+K+H=0
$$

Aux conditions (35) corresponding $\varphi^{r e}\left(\sigma=\sigma_{A f}, T=T 1, f=0\right)=0$

$$
\varepsilon_{0} \cdot \sigma_{A f}-B .\left(T 1-M_{S}^{0}\right)-C+H=0
$$

Finally, we obtain the following system:

$$
\left\{\begin{array}{c}
\varepsilon_{0} \cdot \sigma_{M s}-B \cdot\left(T 1-M_{s}^{0}\right)-C-H=0 \\
\varepsilon_{0} \cdot \sigma_{M f}-B \cdot\left(T 1-M_{s}^{0}\right)+C-K-H=0 \\
\varepsilon_{0} \cdot \sigma_{A s}-B \cdot\left(T 1-M_{s}^{0}\right)+C+K+H=0 \\
\varepsilon_{0} \cdot \sigma_{A f}-B \cdot\left(T 1-M_{s}^{0}\right)-C+H=0
\end{array}\right.
$$

\subsection{Numerical simulation}

The simulation is performed considering the pseudoelastic effect (Fig. 1)

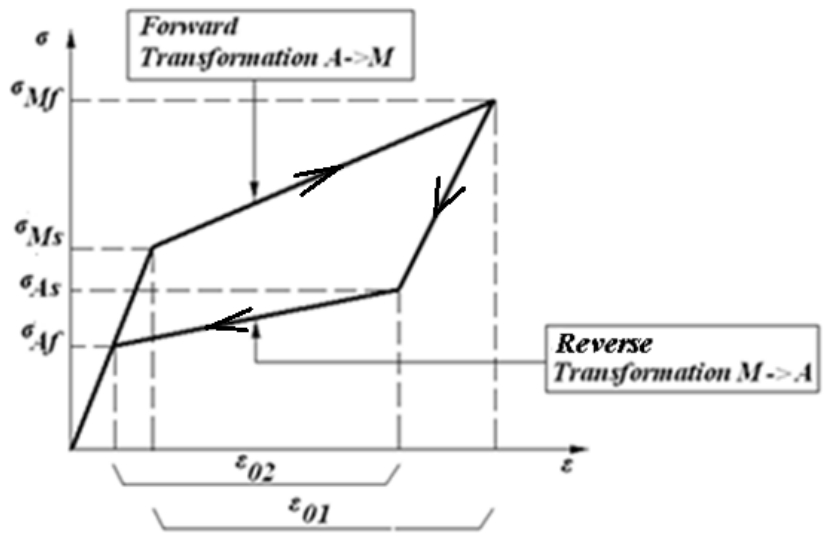

Fig. 1. Effect of pseudoelasticity

Notations in the figure represent:

- $\sigma_{M S}$ : Stress of transformation start of Austenite to Martensite

- $\sigma_{M f}$ : Stress of transformation finish of Austenite to Martensite

- $\sigma_{A s}$ : Stress of transformation start of Martensite to Austenite

- $\sigma_{A f}$ : Stress of transformation finish of Martensite to Austenite 


\subsubsection{Experimental data}

To determine the parameters of the model we have exploited the tensile tests performed on a tube pseudoelastic NiTi (KL Ng, QP Sun 2006), with the test illustrated by Fig. 7. The data are grouped in Table 1.

\begin{tabular}{|l|l|l|l|}
\hline$\sigma_{M S}(\mathrm{MPa})$ & 300 & $A_{s}^{0}(\mathrm{~K})$ & 297 \\
\hline$\sigma_{M f}(\mathrm{MPa})$ & 305 & $A_{f}^{0}(\mathrm{~K})$ & 330 \\
\hline$\sigma_{A s}(\mathrm{MPa})$ & 100 & $\varepsilon_{0}$ & 0.06106 \\
\hline$\sigma_{A f}(\mathrm{MPa})$ & 50 & $\mathrm{~B}(\mathrm{MPa} . \mathrm{K}-1)$ & 0.18746 \\
\hline$E_{A}(\mathrm{MPa})$ & 25775 & $\mathrm{C}(\mathrm{MPa})$ & -0.88082 \\
\hline$E_{M}(\mathrm{MPa})$ & 18442 & $\mathrm{~K}(\mathrm{MPa})$ & -1.44134 \\
\hline$M_{S}^{0}(\mathrm{~K})$ & 279 & $\mathrm{H}(\mathrm{MPa})$ & 8.007499 \\
\hline$M_{f}^{0}(\mathrm{~K})$ & 240 & & \\
\hline
\end{tabular}

Table 1. Experimental data (Ng et al. 2006)

\subsubsection{Boundary conditions and loads}

We consider the following cases:

- One dimensional case: $\sigma_{11}=400 \mathrm{MPa}$

The used specimen is a segment with 1 element:

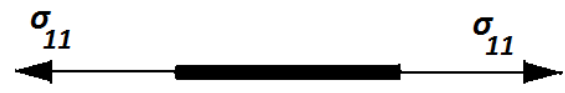

Fig. 2. The simulated specimen is submitted to one dimensional tensile loading

- Biaxial case: $\sigma_{11}=\sigma_{22}=400 \mathrm{MPa}$

The used specimen is a cube with 1 element:

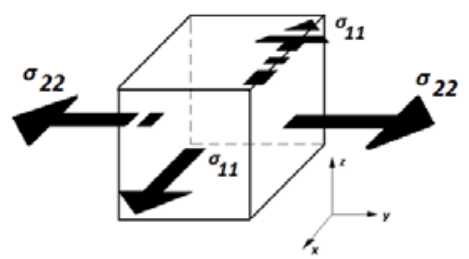

Fig. 3. The simulated specimen is submitted to biaxial tensile loading

- $\quad$ Triaxial case: $\sigma_{11}=\sigma_{22}=\sigma_{33}=400 \mathrm{MPa}$

The used specimen is a cube with 1 element: 


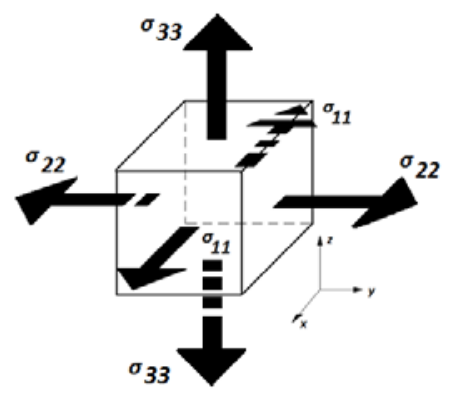

Fig. 4. The simulated specimen is submitted to triaxial tensile loding

\section{Results}

The results are presented for the load cases specified in Section 2.4.2, and discussion of results is given in Section 4.

\subsection{One dimensional case}

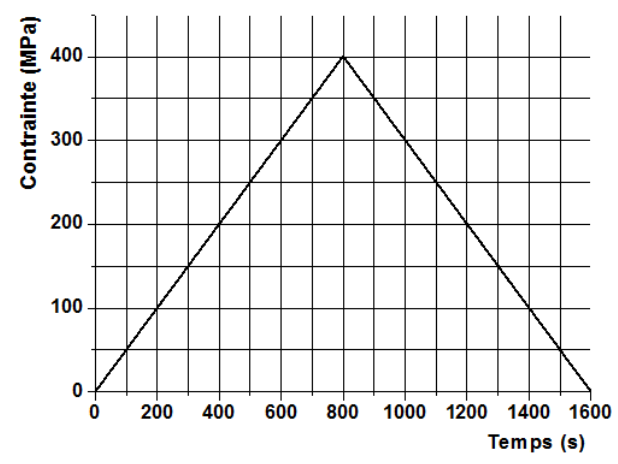

Fig. 5. Loading history

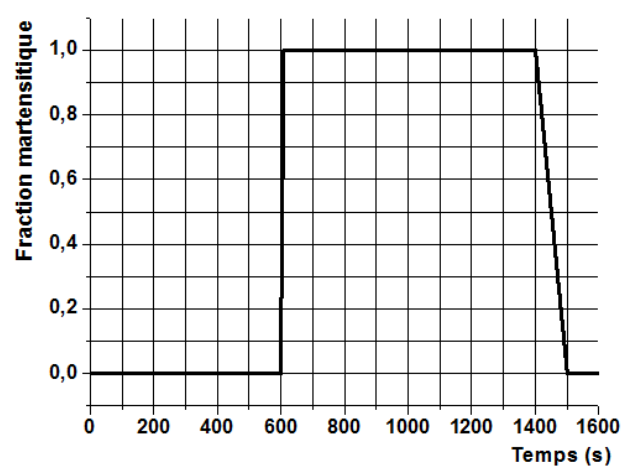

Fig. 6. Evolution of martensite fraction

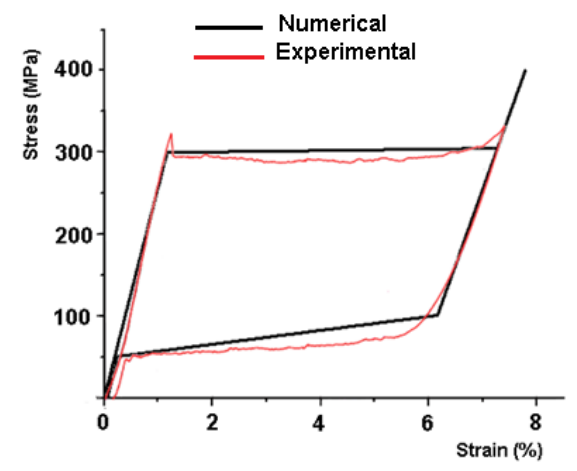

Fig. 7. Comparison between numerical and experimental results, 1D case 


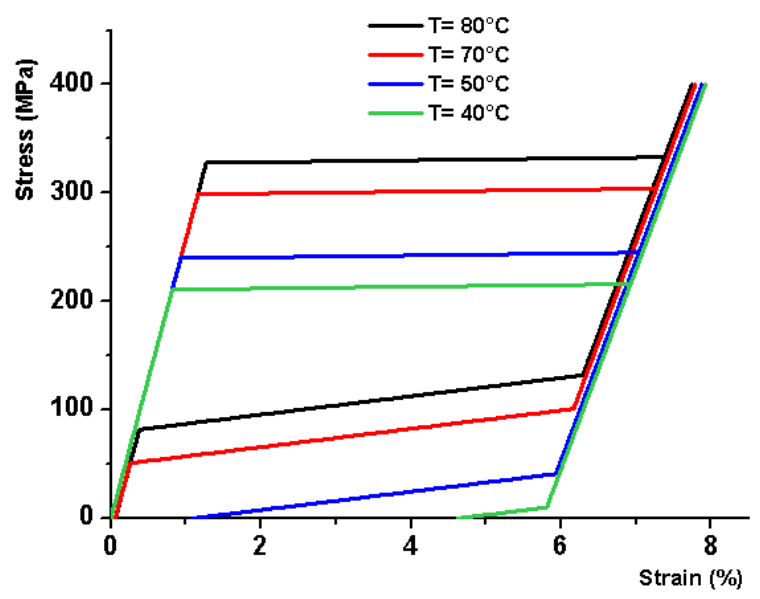

Fig. 8. Response at different temperatures, 1D case

\subsection{Biaxial case}
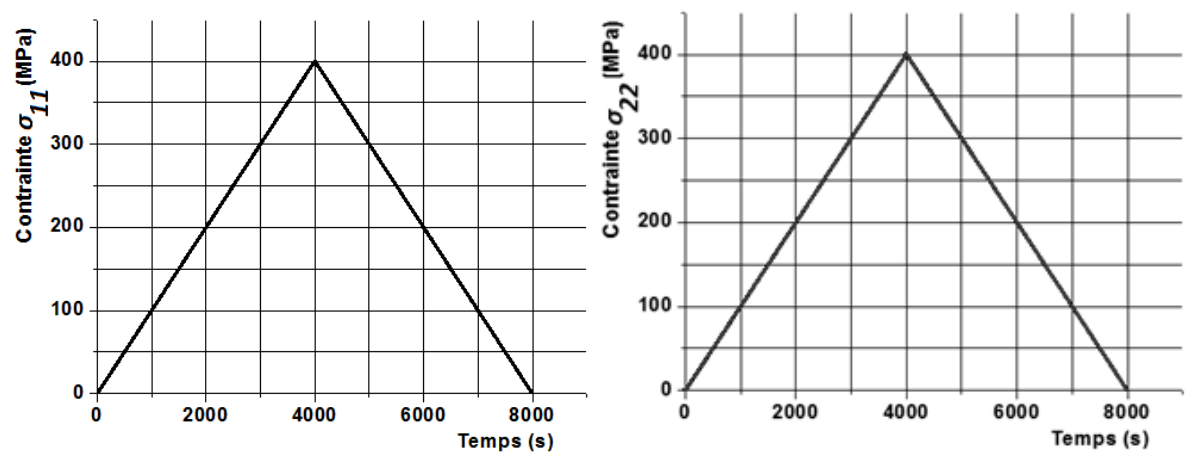

Fig. 9. Loading history

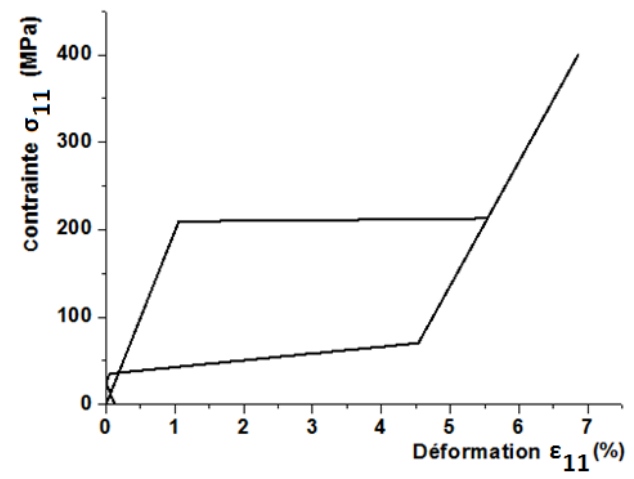

Fig. 10. Plot $\varepsilon_{11}-\sigma_{11}$

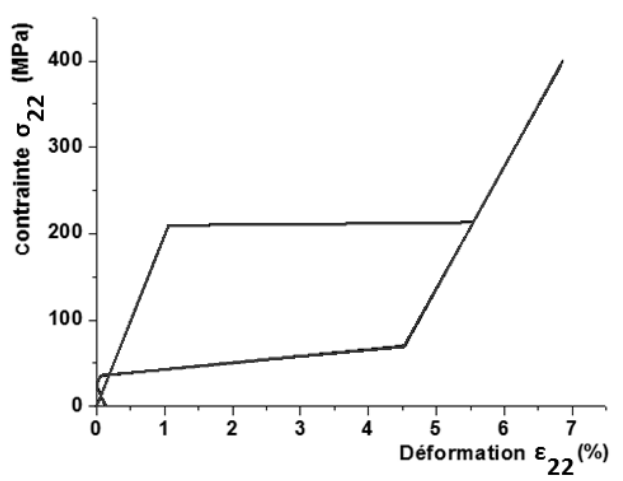

Fig. 11. Plot $\varepsilon_{22}-\sigma_{22}$ 


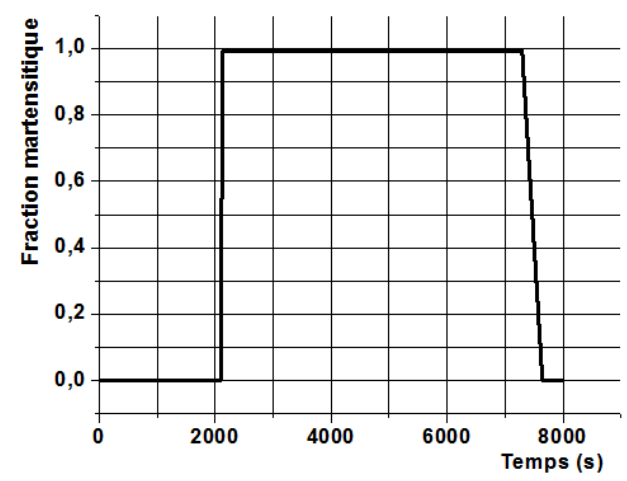

Fig. 12. Evolution of martensite fraction

\subsection{Triaxial case}
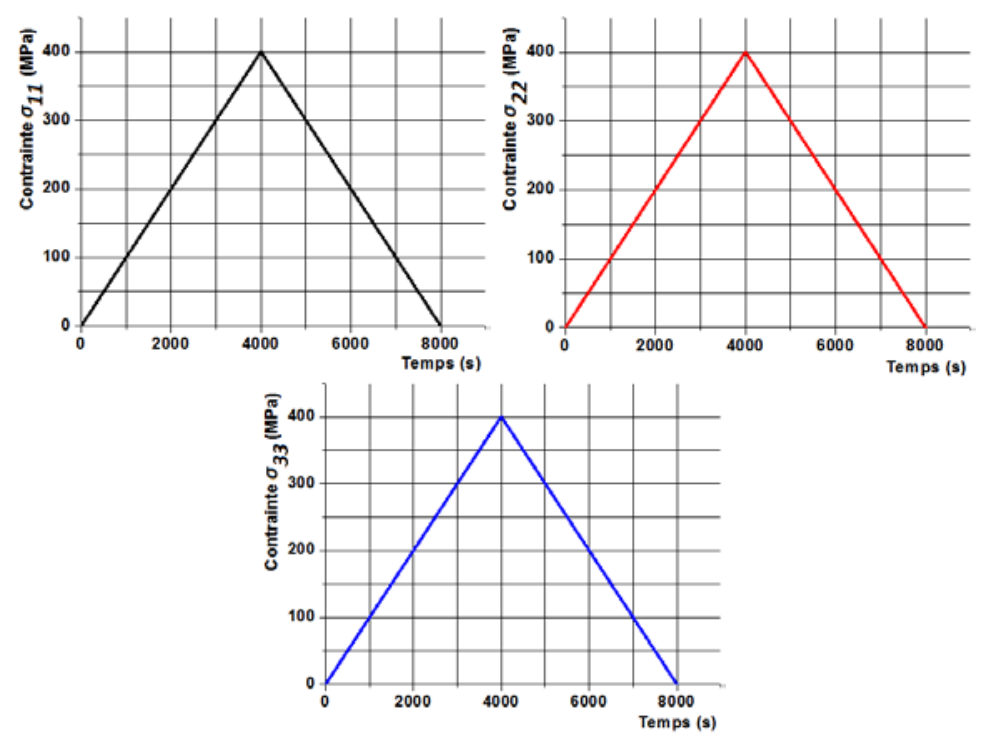

Fig. 13. Loading history

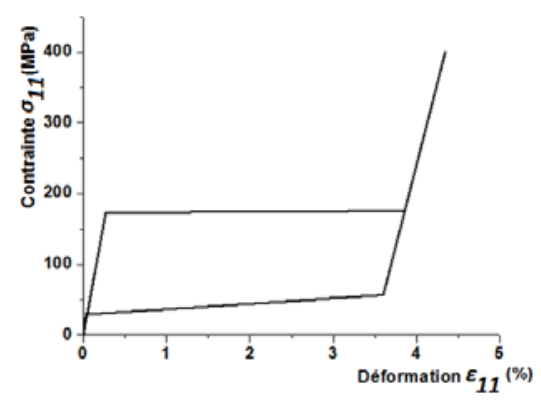

Fig. 14. Plot $\varepsilon_{11}-\sigma_{11}$

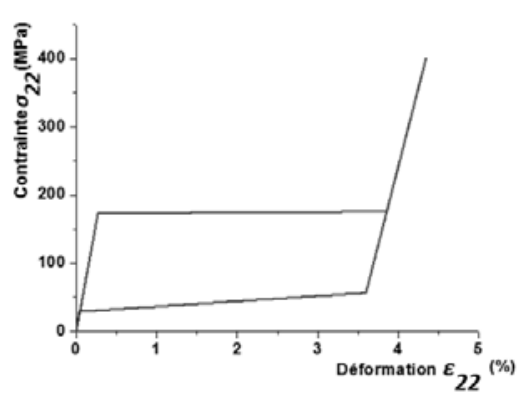

Fig. 15. Plot $\varepsilon_{22}-\sigma_{22}$ 


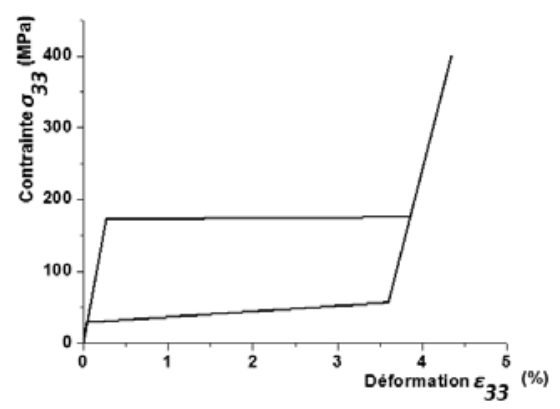

Fig. 16. Plot $\varepsilon_{33}-\sigma_{33}$

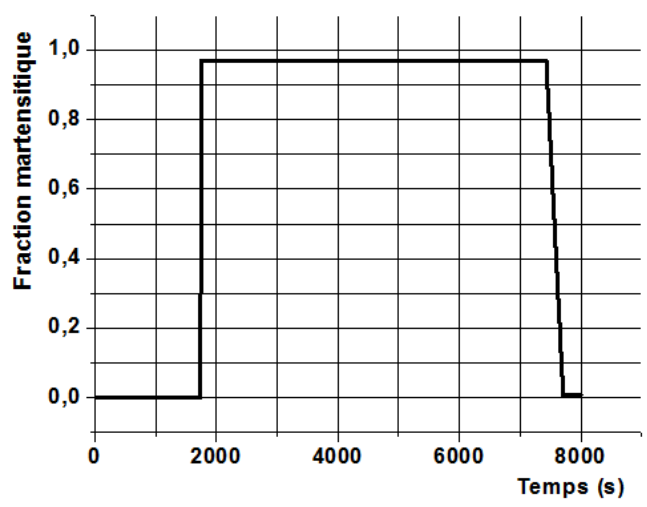

Fig. 17. Evolution of martensite fraction

\section{Discussion}

After inserting the experimental data into algorithm and performing simulation in the above cited cases we have obtained results shown in figures 5 to 17.

By analyzing the results for the three cases we can exibit the following interesting findings.

\subsection{One dimensional case}

Fig. 5 shows that the results of numerical simulation coincide well with the experimental plot. The model responds well and because of being basic, this one-dimensional test has permitted the determination of the parameters of the model which are further used in the remaining cases. Fig. 6 shows an evolution of the martensite fraction composed of three stages: the first is characterized by an increase of the fraction of martensite to vicinity of unity, hence this stage corresponds to the transformation of austenite to martensite; the second stage, where the fraction is constant, corresponds to the large deformation of martensite; and finally, the last stage is characterized by a decrease of the fraction, hence this regime corresponds to the reverse transformation. Fig. 8 shows the response of the model at different temperatures. 


\title{
4.2. Biaxial case
}

An expected response is obtained in this case, where two stresses are applied. Figures 10 and 11 are similar to the one dimensional case. It is noted that the hysteresis shrinks in each direction of stresses because of biaxiality. Fig. 12 shows the evolution of the overall martensite fraction corresponding to the reverse transformation, the large deformation of martensite and the reverse transformation. The aspect of the evolution appears compatible with both strains $\varepsilon_{11}$ and $\varepsilon_{22}$ and similar to the one dimensional case.

\subsection{Triaxial case}

For this tridimensional case where three orthogonal stresses are applied, we observe an analogy with the biaxial case. Figures 14, 15 and 16 show the hysteresis shrinking vertically because of tridimensional loading. The evolution of the martensite fraction (Fig. 17) remains similar to the above $2 \mathrm{D}$ case. We observe the three stages corresponding to the reverse transformation, the large deformation of martensite, and the reverse transformation. The whole evolution is compatible with the three strains $\varepsilon_{11}, \varepsilon_{22}$ and $\varepsilon_{33}$.

\section{Conclusion}

In this work we have developed a 3D constitutive model using the principles of thermodynamics and a simple formalism these principles have permitted to write criteria of transformation. This macroscopic model is developed by simple formalism and assumptions. By using an algorithm we have implemented the model and the response seems to be compatible with the nature of the pseudoelastic effect. In the one-dimensional case we have observed a good agreement between the numerical and experimental plots.

It should be noted that the parameters of the model were determined by the onedimensional test and further used in the biaxial and triaxial cases to ensure consistency of the model in different cases of loading. The implementation of the model in the algorithm is simple and practical. The obtained results testify the usability of the developed model.

In the end, we can say that this macroscopic constitutive model can be used in applications to engineering problems, particularly in order to simulate the pseudoelastic effect of shape memory alloys.

Извод

\section{Тродимензионално моделирање псеудоеластичног ефекта меморијских легура}

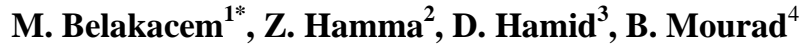 \\ ${ }^{1}$ Department of mechanical Engineering, University of Batna, Algeria \\ samsum66@gmail.com \\ ${ }^{2}$ Department of mechanical Engineering, University of Khenchela, Algeria \\ zedirahamma2003@yahoo.fr \\ ${ }^{3}$ Department of mechanical Engineering, University of Khenchela, Algeria \\ h_djebaili@yahoo.fr \\ ${ }^{4}$ Department of mechanical Engineering, University of Batna, Algeria \\ brio_ray@hotmail.com \\ *Главни аутор
}




\section{Резиме}

Рад има за циљ развијање тродимензионалног конститутивног модела за описивање псеудоеластичног ефекта на понашање меморијских легура. Овај феноменолошки конститутивни модел заснован је на скупу варијабли: температури и напону као контролним варијаблама и фракцији матензита као унутрашњој варијабли. Користећи први и други закон термодинамике и формализам, развили смо конститутивне једначине, а затим и критеријуме трансформације. Развијени модел садржи параметре који се одређују псеудоеластичним тестом затезања. Понудили смо алгоритам који симулира одговоре модела узимајући у обзир експерименталне податке. Узета су у обзир три случаја: једнодимензионално, дводимензионално и тродимензионално оптерећење.

Кључне речи: конститутивни односи, мартензит фракција, меморијске легуре, псеудоеластични ефекат.

\section{References}

Ball J, James R (1992). Proposed experimental tests of a theory of fine microstructure and the two-well problem, Phil. Transactions of the royal Society, Series A, 338, 389-450.

Bhattacharya K (1999). Cristallographic attributes of a shape memory alloy, J. Engineering Materials and Technology, 121, 93-97.

Brinson, LC (1993). One-dimensional constitutive behavior of shape memory alloys: Thermomechanical derivation with non-constant material functions and redefined martensite internal variable. J. of Intell. Mater. Syst. and Struct. 4, 229-242.

Chu C, James RD (1995). Analysis of microstructures in $\mathrm{Cu}-14.0 \% \mathrm{Al}-3.9 \% \mathrm{Ni}$ by energy minimization. Proceedings of the ICOMAT-95, Lausanne, Switzerland.

Falk F (1980) Model free energy, mechanics and thermodynamics of shape memory alloys, Acta Met, 28, 1773-1780.

Govindjee S, Hall GJ (2000). A computational model for shape memory alloys. Int. J. Solids Struct. 37, 735-760.

Huang M, Brinson LC (1998). A multivariant model single crystal shape memory alloy behaviour, J. Mechanics and Physics of Solids, 46, 1370-1409.

Lagoudas DC, Entchev, P B (2004). Modeling of transformation-induced plasticity and its effect on the behavior of porous shape memory alloys. Part I: Constitutive model for fully dense SMAs. Mech. Mater. 36, 9, 865-892.

Lexcellent C, Goo BC, Sun QP, Bernardint J (1996). Characterization, thermomechanical behaviour and micromechanical-based constitutive model of shape-memory $\mathrm{Cu}-\mathrm{Zn}-\mathrm{Al}$ single crystals. Acta Mater. 44, 9, 3773-3780.

Lexcellent C, Leclerq S, Gabry B, Bourbon G (2000). The two way shape memory effect of shape memory alloys: an experimental study and a phenomenological model. Int. J. Plasticity, 16, 1155-1168.

$\mathrm{Ng}$ KL, Sun QP (2006). Stress-induced phase transformation and detwinning in NiTi polycrystalline shape memory alloy tubes. Mechanics of Materials, 38, 41-56.

Patoor E, Eberhardt A, and Berveiller M (1993). On Micromechanics of Thermoelastic Phase Transition, to appear in the proceedings of Plasticity 93: The Fourth International Symposium on Plasticity and Its Applications, held in Baltimore, Maryland, July 19 - 23. 
Tanaka K, Kobayashi, S, Sato Y (1986). Thermomechanics of transformation pseudoelasticity and shape memory effect in alloys. Int. J. Plasticity, 2, 59-72.

Wechsler M, Lieberman D, Read T (1953). On the theory of the formation of martensite, J. of Metals, 197, 1503-1515. 